\title{
At the Flashpoint Between Research and Practice Regional Research and Development Environments as Promotors of Science Communication Begin to Appear
}

\author{
Thomas Tydén*
}

Director of Dalarna Research Institute, Sweden

\begin{abstract}
In this article I have chosen to give a presentation of the growing body of new research environments in Sweden where interactivity is not just a trademark but also a necessity if they are to meet the demands made by public institutions in the local areas in which their research is conducted. This article highlights the development of interactive research as it has been manifested in the various research environments built up by local and county authorities in Sweden. And their role as promotors for science communication is discussed.
\end{abstract}

\section{PERSPECTIVES ON KNOWLEDGE AND COMPE- TENCE DEVELOPMENT}

\section{Excess of Information}

Since radio found its way into every household there has been a huge increase in the availability of one-way mass information. Since the capacity of the human brain is a constant quantity despite this overwhelming supply of information, we are forced to be extremely selective and our ability to sift becomes more and more refined. When we select, our choice is to a large extent based on the credibility of the source and the relevance of the message to us. This increases the value of personal contacts.

\section{High Rate of Change}

People and organisations everywhere are nowadays faced with a considerable amount of change. Conditions change, new technical advances, new methods etc become available. The high rate of change means that the knowledge and competence of professionals have to be constantly adapted and renewed, and a continuous process of education can be a matter of survival.

\section{Evaluation Perspective}

New knowledge and development do not necessarily lead to something positive. Both new knowledge and development may also lead to a deterioration in conditions for people and for the work they do. An important perspective that is often missing is that of evaluation. What kind of knowledge is it that is being made available? In what way may new knowledge affect other aspects of the user's life? What can it mean to be at the receiving end of a transference of knowledge? What consequences does the knowledge have for those who are exposed to it?

\section{Asking the Right Question}

The issues described above raise a number of important questions as to how the transference of information/knowl-

*Address correspondence to this author at the Director of Dalarna Research Institute, Sweden; Tel: +46-23709176; Fax: ++46-23709189;

E-mail: thomas.tyden@dfr.se edge is organised and the value it has for its users. For many professional groups it is therefore important that the orientation of knowledge tranference be changed from the traditional transmitter perspective to a receiver-orientated one. It is more important to know how to pose the question "KNOW WHY" than to have collected a mass of "KNOWHOW" which may be out of date by tomorrow.

A conclusion based on previous studies is that the professional is the one who is able to pose many of the questions that are pertienent to his/her working situation, and who also has the interest and motivation to seek knowledge that can help answer these questions. But having the "theoretical" opportunity to ask questions is not that same thing as always being able to do so in practice. One explicitly problematic area is precisely the matter of how to ask adequate questions, how to pinpoint problems, how to make strategic priorities and see one's work in a wider context. The ability to absorb new knowledge is above all dependent on the individual's capacity to identify and express his/her aims and needs and, on the basis of that, to formulate the question clearly. The first principle is to learn to ask questions - the question is the answer. This underlines the importance for different professional groups of learning to formulate one's problems for oneself, to seek knowledge, to relate to new knowledge (ie to study it critically and evaluate it), to do trend analysis, to make priorities, etc.

In order to succeed with these analyses a growing number of local and regional research institutes that are closely connected to different professionals groups have started in Sweden and this phenomena will be discussed in this article with a focus on the work of local and county authorities.

\section{FOCUS ON THE PUBLIC SECTOR}

A major part of the work of local and county authorities is ultimately concerned with encounters between people: between teacher and pupil, social worker and client, health care staff and patient. The success of such meetings depends on a high degree of professional skill, often based on years of professional experience. Professionalism is generally not something that can be taught through schools and training courses, but rather something that each person laboriously acquires in the course of day-to-day work, in which theories 
confront and complement practice and the individual's own personal qualities. The secret of professionalism is to some extent hidden within the unique make-up of each individual, but certain generalisations are nevertheless possible. To understand these practicians and the nature of their professional qualities, the skills they have acquired through experience must be brought to light and as far as possible put into words. And a greater degree of understanding is needed to make better use of these experiences and to give new colleagues the opportunity of putting these experiences to use in their own practical work. Ultimately it is a question of using limited resources to the best advantage. And the sums of money involved are huge, given that these professional groups account for what is by far the largest part of the public economy.

Research on the practical work of these professional groups requires special tools to get to the essence of their professional skills. One factor that complicates this is that the concept of research is not problematised: instead it is used as if there was general agreement as to what it is. But the issue is not as simple as that. There are a number of research traditions that may well, in varying degrees, play a part in the development of community work practice. Earlier studies clearly indicate the importance to active professionals of reflections based on practical experience, stories and examples given by colleagues (Tydén et al. 2000). The more experienced among them call for a more systematic analysis of work experience, and they often expressed a need to provide this kind of reflection themselves. The academic world may not always be the obvious answer to their needs.

The above gives an indication of the risk involved in the introduction within certain professions of a research approach traditionally found to work for others, before it has been made clear what the preconditions are for such an introduction. Gunbjörg Erlingsdottir (1999) discusses this phenomenon in her thesis with the help of the story of Pandora's box. According to one version of this myth, all that was good in the box was turned to evil when it was opened in the wrong place. Good intentions are transformed into negative consequences when put into practice in the wrong context. Erlingsdottir's thesis dealt with ideas taken from industry being applied to health care, but the example may well be applied to the tendency to follow traditional academic thinking in attempting to make science of social work, teaching, care work etc. However the picture is not a straightforward one, since we have seen an alternative research approach beginning to appear during recent years, with a clear practical orientation, in which the focus is on knowledge and practical work and the interplay between the experiences of researchers and practicians is a central issue. Concepts such as participatory research and interactive research constitute attempts to define this research approach. Many of the researchers involved in this kind of research collaboration with active professionals in the public sector are not to be found within the traditional institutions at the country's universities: instead they are attached to a rapidly growing flora of practically-orientated research institutes that are more or less independent of the university world (Bergström et al. 2000, Tydén 1997)

In this article I have chosen to give a presentation of these new research environments in which interactivity is not just a trademark but also a necessity if they are to meet the demands made by public institutions in the local areas in which their research is conducted. This article highlights the development of interactive research as it has been manifested in the various research environments built up by local and county authorities in Sweden.

\section{REGIONAL RESEARCH AND DEVELOPMENT EN- VIRONMENTS}

During the last twenty years, a large number of regional research environments have come into being in Sweden. In an inventory of publicly-financed research and development organisations that were not affiliated to universities and colleges, carried out by the Dalarna Research Institute in 2000, a budding flora of research activity could be discerned. 82 organisations were listed, mainly active either in health care or the social services (Bergström et al. 2000). These were organisations not mentioned either in national research policy discussions or in the regional growth agreements. This is a growing sector of the research world, at the same time as it is still to a large extent hidden from the public eye. In a follow-up study from 2005 the number of organisations had increased to 108 (Möller 2005).

The majority of the organisations listed do the bulk of their work in areas central to the business of local and county authorities, such as health care and the social services. They reflect a growing commitment to research and development on the part of these authorities. This is in all probability the first stage of an evolution which will make local and county authorities increasingly important actors in this field. Judging by the information in the inventory, they are primarily interested in creating research and development centres within - or in close proximity to - their own fields of activity. This often means interdisciplinary or applied research rather than work within a single discipline.

It is noteworthy that these environments have been created at the same time as the university and college system has expanded in Sweden. There are often links between them as well. In other words, these are complementary rather than competing organisations. It is perhaps natural to regard the growth of these new research and development organisations as a consequence of the universities' and colleges' partial inability to deal with problems raised in the course of publicsector work. Sörlin (2004) is of the opinion that research done at universities takes place according to a system of academic norms and with the object of developing basic knowledge in close contact with teaching. He further feels that it should not be taken for granted that this kind of research furthers economic growth in the same way as research done in close contact with businesses and authorities and geared to satisfying a demand for knowledge originating in the commercial market.

Similar thoughts were expressed in the research strategy document compiled by the Swedish Association of Local Authorities and the Federation of Swedish County Councils during the preparation of the research policy proposal of 2004 (SKL 2003). In the background material I contributed to the strategy document, I argued in terms of the prepositions applied to research (Tydén 2003). I discussed how research affecting local and county councils may be organised so as to benefit their work. One aspect of this is that research 
and development around council work should chiefly, or to a greater degree, take place in collaboration with representatives from this sphere of activity. Research about councils is conducted in varying measure at Swedish colleges and universities. What is required to a much greater extent is research together with local and county councils. These prepositions embody the necessary, complementary ingredients involved in conducting research relevant to local authority work. In what follows, the emphasis will be placed on the preposition with, since it represents a neglected area of state research policy.

The importance of research för improvement and renewal is often dependent on how research is organised in terms of dialogue with representatives from the work area involved, mutual respect for each other's skills and continual interaction. Expressions such as research-based development work or researcher-supported development work may be seen as attempts to capture the essence of this aspect of improvement work.

In the strategy document referred to above, the council associations emphasised that it is therefore important for the coming proposal to make it clear that there is an area separate from research, and also separate from administration, an area whose task is innovation/development - let us say an innovation system - in which research and knowledge play an important part, as do teaching methods, organisational development and administration. It is of course important that the national system accords legitimacy to this area and gives it a measure of financial support without stipulating any form of state control.

Another conclusion is that these new research and development organisations produce new knowledge just as other research organisations do, but that what they create above all is research environments. These envisonments comprise both researchers and practicians, and they highlight the dialogue between these groups and stress the importance of interdisciplinary learning and the combination of different kinds of competence.

I we put a historical perspective on the development of these new research institutes we can note the expansion of public schools in the middel of the $19^{\text {th }}$ led to a change in teaching methods from a form of learning based on experience and concrete problems to teaching tied to written texts. Learning and production environments had to be separated, and the written word took the place of the production environment. For 150 years the emphasis in learning was to be placed on catalogue knowledge (terminology) and analogue knowledge (knowledge of texts) (Dahlgren 2001). But such things as the advent of research environments promoting close collaboration between research and practice, and drawing on co-operation and an exchange of experience between these, lead to what may be termed dialogue knowledge (dis- cussion/exchange/interplay between instrument and human being, or between human beings).

We are now beginning to approach a synthesis of these three kinds of knowledge, although the first two are still to a large extent dominant. It takes time to adapt education to new needs. The tendency is always to carry on in the old ways even though surroundings and purposes change. An analogy may serve as an instance of this. When the first cars began to be produced in the 1880's, they looked strikingly like horse-drawn carriages, and it was several decades before car manufacturers had freed themselves from this left-over of history and started to design cars on the basis of their particular function rather than harking back to the epoch of the horse-drawn carriage. In our case the challenge is to develop research and learning on the basis of post-industrial conditions and free ourselves from the old Taylorist factory ideal.

It is in this context that local and county authorities, by creating new research environments of the kind mentioned above, have been in the forefront of a pioneering development. This new development highlights the dialogue between researcher and practician, and emphasises the need for collaboration on an equal basis. An other explanation for the appearance of these regional research centres outside the traditional academic institutions may be a theoretical discussion about new knowledge production that is currently taking place, as well as a debate about the universities and the ways in which the quest for knowledge is organised (Gibbons et asl 1994). Important new research issues and fields of research have to an increasing extent obliged researchers to work across the boundaries delineated by their own scientific disciplines (Nowotny et al. 2001).

\section{REFERENCES}

Bergström E, Florén A, Ternhag G, Tydén T,(2000), Det dolda universitetet. Framväxten av nya FoU-miljöer utanför universitet och högskolor. DFR-rapport 2000:2, Falun

Dahlgren, L-O (2001), http://www.fryx.vasteras.se/LOD.htm

Erlingsdottir G (1999), Förförande idéer - Kvalitetssäkring i hälso- och sjukvården. Företagsekonomiska institutionen, Lunds Universitet.

Gibbons, Michael. et al. (1994). The New Production of Knowledge. Dynamics of Science in Contemporary Society. Sage, London

Möller P (2005), Forskning och utveckling i kommuner, landsting och regioner - en delrapport från IKA-projektet. Dalarnas forskningsråd, Falun

Nowotny, Helga; Scott, P; Gibbons, Michael (2001), Rethinking Science knowledge and the public in an age of uncertainty. Polity 2001.

Proposition 1959:105, p 39

Sandström U (1994), Mellan politik och forskning. Staten och byggforskningen 1960-1992. Byggforskningsrådet, Stockholm

SKL (2003), En forskningsstrategi för kommuner, landsting och regioner. Svenska kommunförbundet \& Landstingsförbundet, Stockholm.

SOU 1977:52

Tydén T, Josefsson C, Messing J (2000), Socialsekreterare och kunskapsbildning. Socialstyrelsen, Stockholm

Tydén, T., 'Forskningsprogrammet SVEP'. VEST, tidskrift för vetenskapsstudier Vol 2, No 3-4, 1997

Tydén T (2003), 'Forskning och offentlig sektor'. In En forskningsstrategi för kommuner, landsting och regioner. Svenska kommunförbundet \& Landstingsförbundet, Stockholm. 